\title{
In situ analysis of the higher-order genome structure in a single Escherichia coli cell
}

\section{$\operatorname{AUTHOR}(\mathrm{S})$ :}

Shindo, Eri; Kubo, Koji; Ohniwa, Ryosuke L.; Takeyasu, Kunio; Yoshikawa, Kenichi

\section{CITATION:}

Shindo, Eri ... [et al]. In situ analysis of the higher-order genome structure in a single Escherichia coli cell. Journal of Biotechnology 2008, 133(2): 172-176

\section{ISSUE DATE:}

2008-01

URL:

http://hdl.handle.net/2433/49197

\section{RIGHT:}

Copyright (C) 2007 Elsevier B.V. All rights reserved.; This is not the published version. Please cite only the published version.; この論文は 出版社版でありません。引用の際には出版社版をご確認ご利用くださ い。 


\section{Accepted Manuscript}

Title: In situ analysis of the higher-order genome structure in a single Escherichia coli cell

Authors: Eri Shindo, Koji Kubo, Ryosuke L. Ohniwa, Kunio Takeyasu, Kenichi Yoshikawa

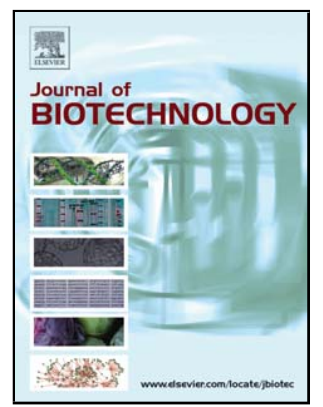

PII:

S0168-1656(07)01518-0

DOI: doi:10.1016/j.jbiotec.2007.08.026

Reference: BIOTEC 4818

To appear in: Journal of Biotechnology

Received date: $\quad 19-1-2007$

Revised date: $\quad$ 28-6-2007

Accepted date: $\quad 9-8-2007$

Please cite this article as: Shindo, E., Kubo, K., Ohniwa, R.L., Takeyasu, K., Yoshikawa, K., In situ analysis of the higher-order genome structure in a single Escherichia coli cell, Journal of Biotechnology (2007), doi:10.1016/j.jbiotec.2007.08.026

This is a PDF file of an unedited manuscript that has been accepted for publication. As a service to our customers we are providing this early version of the manuscript. The manuscript will undergo copyediting, typesetting, and review of the resulting proof before it is published in its final form. Please note that during the production process errors may be discovered which could affect the content, and all legal disclaimers that apply to the journal pertain. 
In situ analysis of the higher-order genome structure in a single Escherichia coli cell

Eri Shindo ${ }^{1}$, Koji Kubo ${ }^{2}$, Ryosuke L. Ohniwa ${ }^{1}$, Kunio Takeyasu ${ }^{1}$, and Kenichi Yoshikawa ${ }^{2}$

${ }^{1}$ Graduate School of Biostudies, Kyoto University, 606-8502, Japan

${ }^{2}$ Department of Physics, Graduate School of Science, Kyoto University \& ICORP, Kyoto 606-8502, Japan

To whom requests for reprints should be addressed:

Kenichi Yoshikawa, Ph. D.

at the Department of Physics, Graduate School of Science, Kyoto University \& ICORP, Kyoto 606-8502, Japan

Tel: $81-75-753-3812$

FAX: 81-75-753-3779

E-mail: yoshikaw@scphys.kyoto-u.ac.jp

key words: optical tweezers, higher-order structure, genome, giant DNA 
Abstract

We developed a novel method for the in situ analysis of the higher-order structure of an individual genome from a single Escherichia coli cell using laser tweezers. Initially, condensed DNA was stably grasped by a laser without any chemical modification and without physical attachment to an artificial object such as micro plastic beads. Under optical transport, the trapped genome gradually unfolded in solution due to viscous friction. Interestingly, the nucleoid DNA from a log-phase cell is almost fully elongated, whereas in the stationary phase, unfolding of the nucleoid is characterized by step-wise elongation of $1.7-5.1 \mu \mathrm{m}$, corresponding to a size of 5-15 $\mathrm{kbp}$, and a few tightly packed domains remain along the DNA chain. This suggests the coexistence of tightly packed and swollen domains in the genome in the stationary phase. 


\section{Introduction}

Manipulation of the whole genome is a challenge in modern biotechnology and

bioscience. Among the various methods used for manipulation, laser tweezers may be promising

because of their ease of use and non-destructive application. Optical tweezers were first developed

in the 1980s by Ashkin (Ashkin, 1997). In most previous studies on DNA manipulation by laser,

optical tweezers have been used to trap beads that are tightly bound to DNA molecules, where the

size of the beads is on the order of $1 \mu \mathrm{m}$ (Bennink et al., 2001; Brower-Toland et al., 2002; Pope et

al., 2002). Thus, the target of optical manipulation has been a plastic bead with a diameter of 1000

$\mathrm{nm}$ that is attached to DNA, where the double-strand structure has a diameter $2 \mathrm{~nm}$. On the other

hand, it is now clear that optical tweezers can stably trap and transport giant DNA (above the size

of several tens $\mathrm{kbp}$ ) under conditions where the DNA molecules are tightly compacted in the

presence of condensing agents, such as, spermine or PEG (Katsura et al., 1998). With optical

tweezers, we can selectively manipulate a desired DNA molecule on the glass plate of an optical

microscope by using suitable staining with a fluorescent dye. It has also been suggested that optical

tweezers may be suitable as a new methodology for gene delivery (Kubo et al., 2003). Since

genome DNAs are generally very long, it would be useful to establish a method for the

manipulation and observation of genome DNA larger than several hundreds of kilo base pairs,

without fragmentation into short DNA chains.

There has been increasing interest in structure and function at the level of single

macromolecules (Zlatanova and van Holde, 2006). Magnetic tweezers have been used to stretch 
DNA (Leuba et al., 2003; Zlatanova and Leuba, 2002). By using DNA molecules that have been chemically attached to micro supermagnetic beads, stretching experiments have been performed on single DNA and single chromatin molecules (Cui and Bustamante, 2000; Murayama and Sano, 2001; Pope et al., 2004). The so-called comet assay has been frequently used to examine the genome structure (Nougayrède et al., 2006; Tice et al., 2000). The comet assay is a method for observing the breakage of DNA under agarose gel electrophoresis, and can be used to detect low levels of damage in genome DNA. To the best of our knowledge, no previous study has examined the stretching of genome DNA in different cell states without the use of micro beads.

In the present study, we analyzed the higher-order genome structure of samples obtained by the lysis of E. coli. To determine the detailed changes in the structure of the genome depending on the growth phase, we also performed the measurements with AFM.

\section{Materials and Method}

2. 1. Bacterial strains and growth conditions

A well-isolated colony of the E. coli strain K-12 on a LB agar plate was transferred to $2 \mathrm{ml}$ of LB medium and cultured at $37{ }^{\circ} \mathrm{C}$ with rotation $(30 \mathrm{rpm})$ to a certain cell density. The cell density was determined by the absorbance at a wavelength of $600 \mathrm{~nm}$.

2. 2. Cell lysis and sample preparation

For the lysis of E. coli, each strain was immersed in $2 \mathrm{ml}$ of a buffer containing, $1 \mathrm{mM}$ $\mathrm{NaN}_{3}$ and $0.1 \mathrm{M} \mathrm{NaCl}$ for $5 \mathrm{~min}$, and lysozyme was added to make the final concentration of $25 \mu \mathrm{g}$ 
/ ml. After 2 min of incubation at $25{ }^{\circ} \mathrm{C}$, a detergent solution containing Brij 58 (polyoxyethylene hexadecylether) and sodium deoxycholate was added to give final concentrations, $0.25 \mathrm{mg} / \mathrm{ml}$ and $0.1 \mathrm{mg} / \mathrm{ml}$, respectively. After $10 \mathrm{~min}$, buffer was diluted 10 -fold by pure water to minimize the effect of detergent on the higher-order structure. The fluorescent dye 4', 6-diamidino-2-phenylindole (DAPI) (to visualize DNA) and 2-mercaptoethanol (2-ME) (as an antioxidant) were added to give final concentrations of $0.4 \mu \mathrm{M}$ and $4 \%(\mathrm{~V} / \mathrm{V})$, respectively. Nile red was added to give a final concentration of $0.2 \mu \mathrm{M}$ to visualize neutral lipids.

For the AFM analysis, cells were harvested from $100 \mu 1$ of culture by centrifugation (13000 xg, $1 \mathrm{~min}$, at $4{ }^{\circ} \mathrm{C}$ ) and washed once with $1 \mathrm{ml}$ PBS (pH 7.2). The cells were resuspended in $250 \mu \mathrm{l}$ of PBS and a $50-\mu 1$ aliquot was placed on a round cover glass $15 \mathrm{~mm}$ in diameter. Extra liquid was removed by blowing with a stream of nitrogen gas. Each strain was immersed in $2 \mathrm{ml}$ of a buffer containing $1 \mathrm{mM} \mathrm{NaN}_{3}$ and $0.1 \mathrm{M} \mathrm{NaCl}$ for $5 \mathrm{~min}$, and $25 \mu \mathrm{g} / \mathrm{ml}$ lysozyme was then added. After 2 min of incubation at $25{ }^{\circ} \mathrm{C}$, Brij 58 and sodium deoxycholate, were added to give final concentrations of $0.25 \mathrm{mg} / \mathrm{ml}$ and $0.1 \mathrm{mg} / \mathrm{ml}$, respectively. After $10 \mathrm{~min}$, the cover glass was dried under a stream of nitrogen gas. The surface of the cover glass was gently washed with distilled water and dried again for AFM analysis.

\section{3. Fluorescence microscopic observation and optical tweezers}

The sample chamber was constructed as shown in Fig. 1 under fluorescence microscopy (OLYMPUS: IX-70). For optical trapping, a Nd: YAG laser (1064 nm) operating at 1W was introduced into an oil-immersed objective lens (OLYMPUS, x100, numerical aperture $=1.30$ ) 
and focused on the stage of an inverted fluorescence microscope. An auto-stage (Sigma Koki) was used to control the movement of a trapped object on the horizontal plane (xy-plane) under the microscope. Fluorescence images were captured by an EB-CCD camera (Hamamatsu Photonics) and recorded on DV-video tapes. These experiments were conducted at $20{ }^{\circ} \mathrm{C}$.

\section{4. AFM analysis}

An atomic force microscope (Nanoscope IIIa, Digital Instrument) was used to image $E$. coli nucleoid structures in air at room temperature under a dynamic force mode with a $100 \mu \mathrm{m}$ scanner. Probes made of a single silicon crystal with a cantilever length of $129 \mu \mathrm{m}$ and a spring constant of 33-62 N/m (OMCL-AC160TS-W2, Olympus) were used for imaging. Data were collected in the height mode with a scanning rate of $0.5-1.0 \mathrm{~Hz}$ and a driving amplitude of $40-80$ $\mathrm{mV}$. Images were captured in a 512 x 512 pixels format and the captured images were flattened and plane-fitted before analysis. Image analysis was performed with the software that was provided with the imaging module (Digital Instrument, USA).

\section{Results and Discussion}

Figure 2 shows a typical fluorescence double-stained image of the single genome DNA in the E. coli cell lysate, where DNA is stained by DAPI and neutral lipids are stained by nile red. This image was captured after the DNA was moved ca. $1 \mathrm{~mm}$ by laser tweezers, and arrows show the point trapped by the optical tweezers. In the DAPI image in Fig. 2, the major fluorescent object remains at the trapped position, and the connected smaller part trails behind. On the other 
hand, in the image stained with nile red, the domain that corresponds to the major part in the DAPI image, can be seen, whereas no fluorescence due to nile red is seen for the small domain observed by DAPI. Neutral lipids effectively emit fluorescence when stained with nile red. A similar observation has been reported in the optical trapping of genome DNA from an Archaea (Oana et al., 2004). Thus, the major domain that is optically trapped is attributable to the consist of condensed DNA and neutral lipids.

Figure 3 shows the process of unfolding of single E. coli genomes during optical transport at a constant speed of $10 \mu \mathrm{m} / \mathrm{s}$. Two different growth phases are shown: log phase on the left and stationary phase on the right. White triangles and arrows indicate the trapping point and direction of transport, respectively. In the log phase, the genome DNA smoothly elongated to over $100 \mu \mathrm{m}$, indicating that the packing is rather loose. In contrast, in the stationary phase, under viscous friction caused by optical transport, the genome showed only partial unfolding that likely reflected intrachain segregation.

The time-dependent changes in length in the log and the stationary phases (Fig. 4) illustrate a marked difference in the manner of physical unfolding. In the log phase, the genome is elongated at an almost constant speed. On the other hand, in the stationary phase, stepwise elongation of the genome was observed. These characteristic changes likely reflect a difference in the activity of the genes embedded in the genome.

In the log phase (Fig. 5, upper), DNA fibers were easily released out of the cell when the cell was lysed under physiological conditions. Close observation by AFM showed that fibers 
were mostly composed of a bead structure, where a statistical analysis of the fiber width revealed two populations at $40 \mathrm{~nm}$ and $80 \mathrm{~nm}$ (Kim et al., 2004). These fibers may be attributable to the thin filaments and small fluorescent objects (Fig. 3 (D, E)). In the stationary phase (Fig. 5, lower), the genome remained tightly packed even after lysis treatment. This tendency corresponds to the results of the fluorescence observation.

In this study, we used a new experimental method with laser tweezers and found a marked difference in the manner of genome packing in E. coil depending on the growth phase. Although under fluorescence microscopy we can only observe DNA molecules with relatively low resolution, we can obtain direct information on the structure in solution without any serious physical treatments such as fragmentation by a restriction enzyme or modification with micro-beads, etc., which may be useful for analyzing the state of giant genome DNA molecules as they exist in cells. On the other hand, AFM revealed detailed information on DNA for a specimen fixed on a solid substrate. Thus, the combination of these two methods should provide more reliable information on what is actually occurring inside a living cell. Most importantly, we showed that optical tweezers can be used in a non-destructive method for the remote handling of single genomes. A preliminary report has shown the utility of laser manipulation of giant DNA molecules from Thermococcus kodakaraensis (KOD1) (Oana et al., 2004), but that study did not examine changes with the growth phase or cell stage. Another study has shown that global changes of structure exists depending on growth phase and environmental stress in E.coli (Ohniwa et al., 2006; Morikawa et al., 2006). Namely genome structure on the growth phase and environmental 
stress may be related in gene expression.

This study found a large difference in the higher-order structure depending on the growth phase by the simple method of optical transport in buffer without any modification of the genome. This novel method may become a powerful tool for revealing the relationship between genome structure and gene activity.

\section{Acknowledgements}

This work was supported in part by a Grant-in-Aid for Scientific Research on Priority Areas (No.17076007) "System Cell Engineering by Multi-scale Manipulation" from the Ministry of Education, Culture, Sports, Science and Technology of Japan. 
References

Ashkin, A., 1997. Optical trapping and manipulation of neutral particles using lasers. Proc. Natl. Acad. Sci. USA, 94, 4853-4860.

Bennink, M. L., Leuba, S. H., Leno, G. H., Zlatanova, J., de Grooth, B. G., Greve, J.,2001. Unfolding individual nucleosomes by stretching single chromatin fibers with optical tweezers.

Nat. Struct. Biol. 8, 606-610.

Brower-Toland, B. D., Smith, C. L., Yeh, R. C., Lis, J. T., Peterson, C. L., Wang. M. D., 2002.

Mechanical disruption of individual nucleosomes reveals a reversible multistage release of

DNA. Proc. Natl. Acad. Sci. USA, 99, 1960-1965.

Cui ,Y., Bustamante, C., 2000. Pulling a single chromatin fiber reveals the forces that maintain its higher-order structure. Proc. Natl. Acad. Sci. USA, 97, 127-132.

Katsura, S., Hirano, K., Matsuzawa, Y., Yoshikawa, K., Mizuno, A.,1998. Direct Laser Trapping of Single DNA Molecules in the Globular State. Nucl. Acids Res., 26, 4943-4945.

Kim, J., Yoshimura, S. H., Hizume, K., Ohniwa, R. L., Ishihama, A., Takeyasu, K., 2004.

Fundamental structural units of the Escherichia coli nucleoid revealed by atomic force microscopy. Nucl. Acids Res., 32, 1982-1992.

Kubo, K., Ichikawa, M., Yoshikawa, K., Koyama, Y., Niidome, T., Yamaoka, T., Nomura, S. M., 2003. Optically driven transport into a living cell. Appl. Phys. Lett., 83, 2468-2470. 
Leuba, S. H., Karymov, M. A., Tomschik, M., Ramjit, R., Smith, P., and Zlatanova J., 2003. Assembly of single chromatin fibers depends on the tension in the DNA molecule: Magnetic tweezers study., Proc. Natl. Acad. Sci. USA, 100, 495-500.

Morikawa, K., Ohniwa, R. L., Kim, J., Maruyama, A., Ohta, T., Takeyasu, K., 2006. Bacterial nucleoid dynamics: oxidative stress response in Staphylococcus aureus. Genes to Cells, 11, 409-423.

Murayama, Y., Sano, M., 2001. Force Measurements of a Single DNA Molecule in the Collapsing Phase Transition. J. Phys. Soc. Jpn, 70, 345-348.

Nougayrède, J.-P., Homburg S., Taieb, F., Boury, M., Brzuszkiewicz E., Gottschalk G., Buchrieser, C., Hacker, J., Dobrindt, U., Oswald, E., 2006. Escherichia coli Induces DNA Double-Strand Breaks in Eukaryotic Cells. Science, 313, 848-851.

Oana, H., Kubo, K., Yoshikawa, K., Atomi, H., Imanaka, T., 2004. On-site manipulation of single whole-genome DNA molecules using optical tweezers. Appl. Phys. Lett. 85, 5090-5092.

Ohniwa, R. L., Morikawa, K., Kim, J., Ohta, T., Ishihama, A., Wada, C., Takeyasu, K., 2006.

Dynamic state of DNA topology is essential for genome condensation in bacteria. EMBO J., 25, 5591-5602.

Pope, L. H., Bennink, M. L., Greve, J., 2002. Optical tweezers stretching of chromatin. J. Muscle Res. Cell Motil. 23, 397-407.

Pope, L. H., Bennink, M. L, van Leijenhorst-Groener, K. A., Nikova, D., Greve, J., Marko J. F., 
2005. Single Chromatin Fiber Stretching Reveals Physically Distinct Populations of Disassembly Events. Biophys. J. 88, 3572-3583.

Tice, R. R., Agurell, E., Anderson, D., Burlinson, B., Hartmann, A., Kobayashi, H., Miyamae, Y., Rojas, E., Ryu, J.-C., Sasaki, Y. F., 2000. Single cell gel/comet assay: Guidelines for in vitro and in vivo genetic toxicology testing. Environ. Mol Mutagen, 35, 206-221.

Zlatanova, J., Leuba, S. H., 2002. Stretching and imaging single DNA molecules and chromatin. J. Muscle Res. Cell Motil., 23, 377-395

Zlatanova, J., van Holde, K., 2006. Single-Molecule Biology: What Is It and How Does It Work? Mol. Cell, 24, 317-329. 


\section{Figure Captions}

Fig. 1. Schematic cross-sectional view of the experimental set-up. The single genome DNA in the lysate of a $E$. coli is trapped and transported in buffer solution by optical tweezers.

Fig. 2. Fluorescence images of a double-stained cell in the stationary phase.

A: Image of a cell visualized by DAPI.

B: The same cell visualized by nile red.

C: The same cell before transport.

White triangles and arrows indicate the trapping point and direction of transport, respectively.

Fig. 3. Mechanical unfolding of a single E. coli genome DNA visualized by DAPI during transport in buffer solution with optical tweezers. Pictures on the left are fluorescence microscopic images, and those on the right are quasi-three-dimensional representations of the spatial distribution of fluorescence intensity on the genome.

Fig. 4. Change in the long-axis length of genome during transport by optical tweezers for both the log phase and stationary phase.

Fig. 5. AFM images of lysed E. coli in the log phase (upper) and stationary phase (lower). In the $\log$ phase, the genome is mechanically unfolded into a thin filament, when the E. coli cells were lysed. In stationary phase, most of the genome is tightly compacted. Scale bar: $500 \mathrm{~nm}$ 




Shindo et al., Figure. 1 


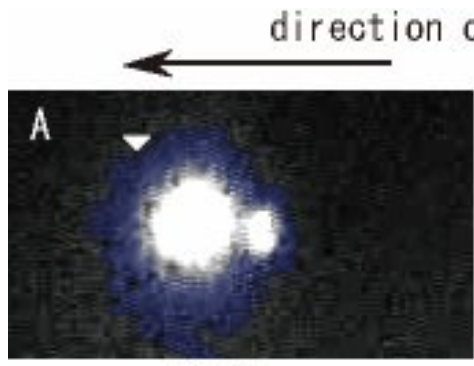

DAPI

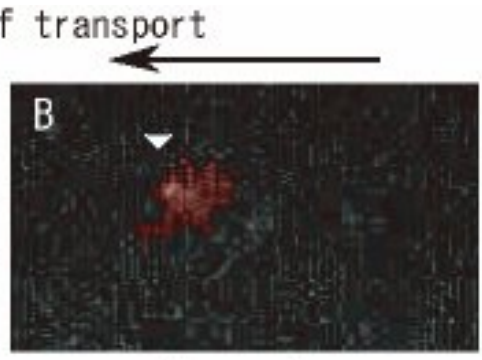

nile red



before transport

Shindo et al., Figure. 2 

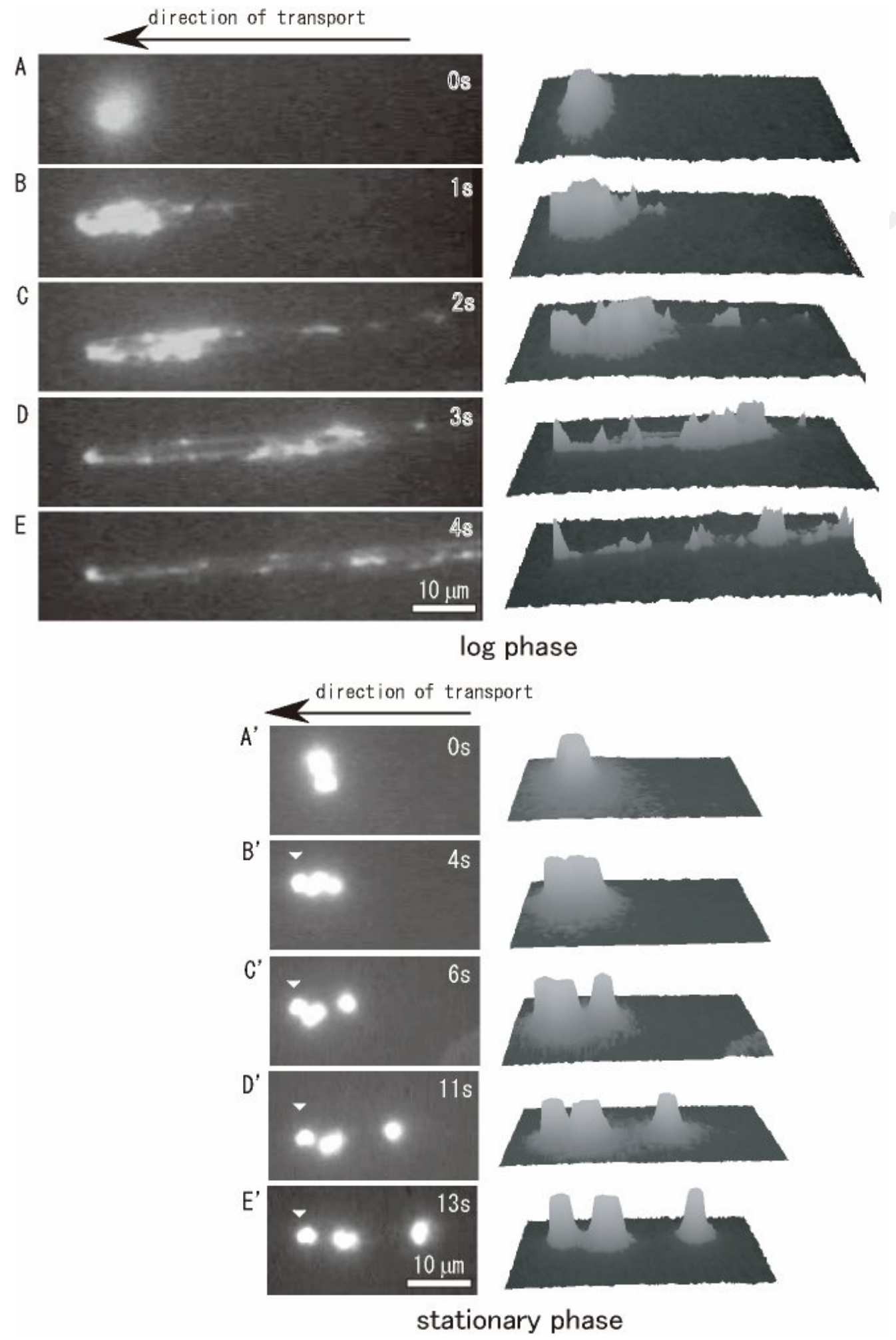

Shindo et al., Figure. 3 




Shindo et al., Figure 4 

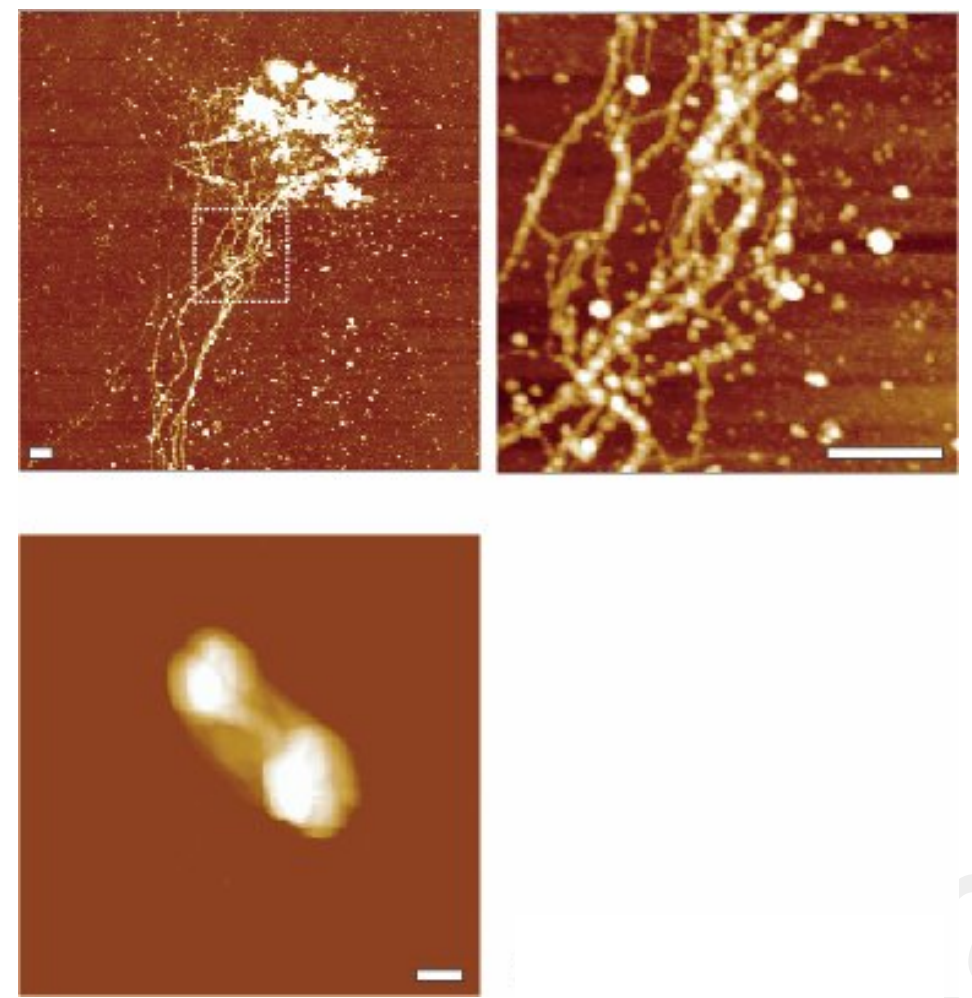

Shindo et al., Figure 5 